\title{
THE EROTIC AND THE VULGAR \\ Visual Culture and Organized Labor's Critique of U.S. Hegemony in Occupied Japan
}

\author{
Christopher Gerteis
}

ABSTRACT: This essay engages the colonial legacy of post-war Japan by arguing that the political cartoons produced as part of the post-war Japanese labor movement's critique of U.S. cultural hegemony illustrate how gendered discourses underpinned, and sometimes undermined, the ideologies formally represented by visual artists and the organizations that funded them. A significant component of organized labor's propaganda rested on a corpus of visual media that depicted women as icons of Japanese national culture. Japan's most militant labor unions were propagating anti-imperialist discourses that invoked an engendered/endangered nation that accentuated the importance of union roles for men by subordinating, then eliminating, union roles for women.

By the summer of 1948, U.S. officials had come to believe that each wave of labor militancy to sweep Occupied Japan originated in the Soviet Union, and they began to reexamine what had been to that point a genuine attempt to encourage the growth of an independent labor movement in post-war Japan. Despite little evidence of Soviet involvement, the U.S. military high command responded to the perceived threat by suppressing Japan's most militant labor unions. Indeed, when retelling the start of this radical shift in Allied Occupation policy, thought to mark the start of the cold war in Japan, scholars, pundits, and union activists often make use of the moment in August 1948 when U.S. troops suppressed a strike of unionized film workers at the Tōhō Motion Pictures Studio. The Tōho Strike has been a useful, colorful anecdote of the moment when Allied Occupation officials launched a drastic policy shift since known simply as the "Reverse Course." 1

\footnotetext{
${ }^{1}$ Many readers will already be knowledgeable about how in the first two and a half years of the Allied Occupation of Japan Allied officials commenced a wide array of social, economic, and political reforms intended to create a post-war Japanese society that could never again raise arms against the United States or its allies. Occupation planners believed both land redistribution in the coun- tryside and labor unionization in the cities were essential to the democratiza- tion of Japan. Indeed, land reform created a strong base of politically conservative "yeoman farmers" in rural Japan. Japan's labor movement, how- ever, grew strongest and fastest within militant unions that had strong ties to the Communist and Socialist parties. The shift in U.S. policies toward Oc- cupied Japan known as the "Reverse
} 
This essay focuses on visual propaganda produced by militant unions active during the summer of 1948, the moment generally understood by labor activists to mark the start of the Allied Occupation's turn against the left-led labor movement. The aim is to show how even the radical ideologies found at the margins of post-war Japanese society were deeply informed by notions of gender that undermined their formal assertions of women's equality. Indeed, visual representations of gender roles act as discourses that convey a set of commonly held beliefs about social roles ascribed to sex (the substance of what I mean by the term gender) while simultaneously instilling social meaning that the artist consciously intended. I argue that the political cartoons produced by Japan's post-war labor unions show how gendered discourses underpinned, and sometimes undermined, the ideologies formally represented by the artists and the organizations that funded them.

My analysis builds on studies of pre-war and wartime Japan that demonstrate how a variety of organizations - whether politically left or right, but all male dominant though majority female - have deployed to different degrees elaborate iconographies of "woman" as a means of depicting their discrete agendas. $^{2}$

Indeed, the sources are rich, and Japanese women have been present-butunrepresented. However, pioneering studies of the visual culture produced by labor unions of the early twentieth century in the United States and Japan document how in fact organized labor has often used "woman" as a core signifier in the near total absence of actual women union members. ${ }^{3}$

Labor's iconographies of "woman" also served to obscure a significant history of women's workplace activism outside the context of established labor

Course" was the result of the escalation of cold war tensions in the Far East. See Dower 1999; Takemae 2002; and Moore 1983.

${ }^{2}$ In particular, see Mackie 1997; Mackie 2000; Mackie 2003; Tamanoi 1998; and Tamanoi 1999.

${ }^{3}$ The literature concerning the impact of gender norms on labor propaganda is diverse. Elizabeth Faue (1991) documents how Minneapolis-based labor un- ions used an iconography of "woman" to signify their political agenda, often to the detriment of the women activists responsible for mobilizing the communi- ties in which they lived. Greta Bucher (2000) illustrates how the Soviet State also used iconographies of womanhood to illustrate many political campaigns in the 1950s. Elena Osokina (2001) does likewise. The Japanese labor propa- ganda of the postwar era borrows heavily from the visual propaganda of pre- war Japan as well as the People's Republic of China. Ellen Johnston Liang (1988) examines the socialist realist propaganda art of the PRC, a considerable amount of which implemented discourses of both masculine and feminine, and a side-by-side reading of the PRC and Japanese propaganda suggests a cor- relation backed by the political discourses of the Communist and Socialist par- ties in Japan. 
unions. ${ }^{4}$ In the case of pre-war Japan, Vera Mackie uncovers how nascent socialist and labor movements often used representations of working and working-class women as discursive signifiers of key political and economic objectives. Yet, neither movement evolved to attract more than a few thousand wage-earning women members. It appears that the primary reason for deploying "women" during the pre-war era was as a means to organize wage-earning men. ${ }^{5}$

Pre-war managers seeking strategies to deflect class-tensions in the workplace concurrently deployed ideologies of gender and race. Elyssa Faison argues that to preempt union activism among its predominantly female workforce, textile company propaganda portrayed the company as a family and management as its patriarch - to the point that in the 1920s, female textile workers were more often defined as "woman" than as "worker." Faison further argues that over time "femininity itself came to be used as a 'boundary marker' deployed as a rearguard action against the onslaught of the rapid social change associated with industrialization and an expanding empire. As the textile industry incorporated larger numbers of low-waged colonial subjects, ethnicity displaced gender as the "privileged signifier precisely because 'woman' in Japanese labor relations had already been defined as 'Japanese." By the 1930s, Japanese men were "classed," Japanese women "gendered," and colonial subjects "ethnicized."

The discourse after 1945 mimicked much of the pre-war form. However, the legal framework imposed by the U.S.-dominated Allied Occupation government yielded both a larger labor movement and a wider field of participation for women. By 1948, some eight thousand unions claimed a total of more than 1.5 million women members - a number far larger than at any time previous. ${ }^{7}$ This article puts into stark relief the degree to which simultaneous ideologies of gender and race underpinned the visual discourses deployed by several key labor unions in post-war Japan.

While Japan's post-war unions could claim to represent a much larger population of wage-earning women than did their pre-war predecessors, union propaganda depicting the category "woman" revealed far more about, and did far more for, the men who led the labor movement than the women being represented. Living under the shadow of what they feared was an emerging American hegemony in Northeast Asia, Japan's militant socialist unions were by the summer of 1948 deploying anti-imperialist discourses invoking an engendered/endangered nation that accentuated the importance of union roles for men by first subordinating, then eliminating, those for women. As a result, the visual propaganda that unfolded around the 1948 strike at the Tōhō Motion Picture Studios reveals a deeply gendered iconography of class struggle,

\footnotetext{
${ }^{4}$ Patricia Tsurumi (1991) documents women's labor activism outside the con- text of labor unions, as does Sharon Sievers (1987) and Barbara Molony (1991) and Yoshiko Miyake (Miyake 1991).

${ }^{5}$ Mackie 1997.

${ }^{6}$ Faison 2001, 34-36.

${ }^{7}$ Takahashi 1992, 12.
} 
which makes plain that the interests of women would be re-subordinated to those of men. ${ }^{8}$

\section{A Strike of Film Workers}

During the mid and late 1940s, the film workers union local representing stage and theater workers at the Tōhō Motion Picture Company was the darling of the militant leftist labor movement and as such was a principal producer of politicized visual culture in Occupied Japan. Organized in January of 1946, the Tōhō local of the National Film and Theater Workers' Union (NFTWU, Nichieien) was the national umbrella organization for several hundred union locals representing nearly fifteen thousand film, stage, and theater workers across the nation. Most union locals were tightly run by representatives handpicked by the national, which had strong ties to both the militant National Congress of Industrial Unions (NCIU, Sanbetsu Kaigi) and the Japan Communist Party (JCP). After two strikes in 1946 and 1947, the film workers at Tōho were among the first unions in Japan to win a guaranteed minimum monthly salary, a shop steward system, an eight-hour workday, a detailed grievance resolution system, and a labor committee system gave unions considerable control over studiolevel production decisions. The rights the NFTWU had won were a model of success and the pride of the NCIU. ${ }^{9}$

Prominent business leaders, acutely aware of the political implications of the union's contract, encouraged Tōhō executives to find a way to break the union. In a secret meeting held in the Yoyogi district of Tokyo, leaders of the newly founded business group Nikkeiren agreed to a plan that would put a stop to the $\mathrm{NClU}$ 's attempts to win control of industrial production - even in cases where a union, such as at Tōhō, had done so through established legal means. A small delegation from Nikkeiren approached the Tōhō executives to offer them financial support, in the form of preferential loans, on condition that Tōho managers attempt to break the film workers' union. ${ }^{10}$

In January 1948, Tōhō president Watanabe Tetsuzō declared that he would "deal with Tōhō's two Reds" - a red budget and a Red union. By spring, he had disbanded the contractually mandated shop steward and production committee systems and canceled all union-endorsed productions at the studio. Union leadership strongly protested, and both parties suspended all further

\footnotetext{
${ }^{8}$ Okochi Kazuoin Roundtable 1971, 165-66.

${ }^{9}$ At the time of the 1948 strike, the NFTWU represented workers in all of Tōhō's film production units as well as the Tōhō Company's projection, theater, and stage divisions. Of particular importance was the union-management commit- tee system that gave the union considerable power over daily management de- cisions at the studio, and in some ways implemented part of the NCIU's vision for a workercontrolled enterprise. Although the NFTWU won these rights through tactics consistent with the legal framework set up by Occupation au- thorities, business leaders, government officials, and U.S. personnel did not appreciate the union's inroads into traditional management prerogatives. Ōkōchi 1969, 263-64; and Kurosawa 1982, 166-67.

${ }^{10}$ Price 1997, 66.
} 
discussions. ${ }^{11}$ Watanabe also sponsored the formation of an anticommunist rival union by granting a small group of twenty-two employees the union-right of a closed shop, with the proviso that the new Tōhō Employee's Union would strictly exclude "communists and their sympathizers." Most Tōhō workers in Tokyo rejected the company union; however, more than 80 percent of the workers at the off-site Stage Properties Division joined the new union, which pointedly did not affiliate with either the NFTWU national or its organizational umbrella the $\mathrm{NCIU} .^{12}$

The split proved a significant blow to the morale of NFTWU members, and with a splinter union in his camp, Watanabe appeared well positioned to break the NFTWU Tōhō local in Tokyo. When the contract deadline passed in March 1948, Watanabe summarily dismissed more than one thousand workers nationwide, specifically targeting NFTWU leaders and activists. ${ }^{13}$ He told Allied officials with the Labor Division at General Headquarters (colloquially known in Japan as $\mathrm{GHQ}$ ) that his aim was to purge the company of all "known communists" and replace the militant NFTWU Local with the Tōhō Employee's Union he had sponsored. ${ }^{14}$

NFTWU workers responded to the mass dismissal by seizing control of the Number One Production Studio located in the residential Kinuta neighborhood of Tokyo (Setagaya Ward). At the impetus of NCIU organizers, sympathy strikers from the Communist Youth League, the Industrial Labor Association, and the North Korean Workers Association joined the strikers in occupying the studios - swelling the actual number of sit-down strikers to nearly a thousand. NCIU propaganda urged participants to rally in support of the union with slogans calling on all "citizens to defend the independence of Japanese culture and democracy." 15

The sit-down strike at the Tōhō Kinuta Studio was not the first militant workplace seizure during the Occupation period, but it was by far the one with the highest public profile. Because the studio at Kinuta was the home of such blossoming post-war talent as director Akira Kurosawa and actor Toshirō Mifune, the press reported regularly on the progress of the strike. The mainstream press covered the strike from the perspective of management and

\footnotetext{
${ }^{11}$ Watanabe 1956, 317-39; and Hirano 1984, 147.

${ }^{12}$ General Headquarters (GHQ), Civil Censorship Division (CCD), Press Publica- tions and Bulletins Division (PPBD), Theatrical Section "Memorandum for Re- cord: re. Anti-Communist Movement in Tōhō," GHQ, CCD. PPBD, Theatrical Section, 7 April 1948. Memo for Record, Motion Picture Section, (RG311, Box 8580, Folder 11), National Archives and Records (NARA), Archives II, College Park, Maryland.

${ }^{13}$ Watanabe 1956, 317-39; Economic and Scientific Section (ESS), Labor Divi- sion, "Memorandum for Record: re. Tōhō Studios," 9 April 1948. Chronologi- cal Files, Jan 48-Apr 48 (RG331, Box 8477, Folder 8), NARA.

${ }^{14}$ CCD, PPBD, Motion Picture Section, "Memorandum for Record: re. New Offi- cers of Tōhō Co. Ltd.," 21 January 1948. Ōkōchi 1969, 263-64.Memo for Record, Motion Picture Sec- tion, (RG331, Box 8580, Folder 11), NARA.

${ }^{15}$ Okochi 1969, 263-64.
} 
government, which saw their opposition to the strike as a defense of the sanctity of property law and the state's ability to enforce it. At first, the national labor and socialist press focused on how the Tōhō Strike was about the right of workers to assert collective control over the course of their livelihood. The NFTWU Tōhō local, however, decried in its weekly newsletter, pamphlets, and posters that the stakes were even higher: claiming that most at risk was the nature of Japanese culture and the survival of the post-war democracy. ${ }^{16}$

\section{Propaganda}

As befit a union of filmmakers, strike propaganda was colorful and dramatic. The strike presented union propagandists with an unprecedented opportunity to orchestrate a pro-labor media campaign that included the participation of some of Japan's most famous film stars and directors. Ranking officers at GHQ feared that the high-profile strike was precisely the platform the NCIU, in collaboration with the Communist Party, needed to mount a direct challenge to Allied authority in Occupied Japan. Strike leaders regularly orchestrated demonstrations, punctuated with appearances by film stars - all well covered by the mainstream press. ${ }^{17}$

The three national daily newspapers presented a narrative of the strike generally sympathetic to the union, and the 1948 Tōho strike saw the culmination of several years of collaboration between the film workers' union and an array of newspaper and magazine writers.

In May, the NCIU and Tōhō union invited sympathetic writers, artists, and activists to attend a meeting in the Kanda neighborhood in Tokyo in order to learn how they could better collaborate with the cultural programming under development in support of the Tōhō union. Author and activist Miyamori Shigeru recalled that the meeting sought to educate leftist artists on how they could work with organized labor to develop cultural materials that resisted bourgeois liberalism. Miyamori also recalled that the "Cultural Works Defense Meeting" (Hataraku mono no bunka mamoru kai), held on May 15, was not particularly successful in that it attracted artists and writers already sympathetic to the cause.$^{18}$ However, Miyamori asserted that the meeting

${ }^{16}$ From the author's survey of the published and unpublished materials of the Tōhō local and NTFWU national (Folders D-20: 5-4, Nichieien 1948 I-V, and Tōhō Sōgi 1948) in the Papers of the Sanbetsu Kaigi held by the Ōhara Institute for Social Research, Hōsei University; review of Mainichi Shimbun, and Asahi Shimbun, 1948; and the Nichieien Tōhō materials collected in Yamamoto 1986.

${ }^{17}$ In March 1948, for example, the union orchestrated an appearance by Kuga Yoshiko and Ikebe Ryō singing union songs and waving the Communist Party flag.

${ }^{18}$ The NCIU's interest in defending what its strike propaganda referred to as the national culture (minzoku bunka) coincides with conservative efforts to lay claim to the notion of a "cultural nation" (bunka kokka). Although diametri- cally opposed, conservative and leftist movements were similarly conceived as cultural interventions: one to build a conservative liberal bourgeois, the other to build a socialist Japan - and both under the umbrella of a U.S. social engi- neering project. For a discussion of Yoshida Shigeru's role, see Siegenthaler 2000 
strengthened the commitment of those in attendance to the kinds of antiimperialist propaganda NCIU leaders were calling for. ${ }^{19}$

A significant part of the Tōhō union's propaganda campaign relied on carefully orchestrated confrontations between striking workers and police, company representatives, and members of a company-sponsored "back-to-work" organization. Union artists and affiliated writers also produced newspaper articles, banners, pamphlets, posters, and placards that decried how the rise of capitalist dominance of the film industry, underscored by the Tōhō Company's firing of its unionized workers, was a serious threat to Japanese culture. ${ }^{20} 20$

A significant component of the Tōhō union's propaganda campaign also rested on a corpus of visual media depicting Toho's women union members. In June 1948, the centrist daily newspaper Mainichi photographed the "Tōhō Union Women" - clerical workers, stagehands, and Tōhō's stable of film actresses

- who marked the end of each strike day by marching out the studio gate chanting slogans and singing union songs. In early August, Mainichi captioned a photograph of a dozen Tōhō actresses, sitting around a small table laden with snacks, tea cups, and a large tea kettle, discussing amongst themselves the "implications of a proposed strike settlement." ${ }^{21}$

The Tōhō Women's Department staged these women's meetings and marches with the idea that what union propagandists referred to as the "star power" (sut $\mu$ paw $\mu$ ) of unionized actresses might attract additional public sympathy for the strike. ${ }^{22}$ However, former Tōhō Women's Department chief Ishikawa Masako explained that this particular role was not the one intended by the women who had formed the organization. Women activists had wanted the Tōho Women's Department to be an advocate for the equal status of women within both the union and the workplace. In late 1947, the union's Strike Committee suggested to Ishikawa and her colleagues that they organize the Tōho Women in a manner that would help the union appear more sympathetic to the public, even as they were being asked to push aside their concerns as an organization founded to struggle for women's issues and focus on the larger interests of the union as a whole. ${ }^{23}$

\footnotetext{
${ }^{19}$ Miyamori 2002, 55-60, 153-57.

${ }^{20}$ Moore 1991, 453-78; Okōchi Toshio 1948. Poster slogans "Hataraku mono no eiga engeki wo mamore!" "Tōhō no sōgi wo kyōdō tōsō de kachi tase yō!" Ni- hon eiga engeki rōdō kumiai/Nichieien/Tōhō, held by the Ōhara Institute for Social Research Digital Archives, PB0171: $26 \mathrm{~cm}$ x $36 \mathrm{~cm}, 1948$; and "Mamore minzoku bunka," "Tōhō wo kachitaseyō!" Nihon eiga engeki rōdō kumiai/ Nichieien/Tōhō, Ōhara Institute for Social Research Digital Archives, PB0170: 25cm x 36cm, 1948.

${ }^{21}$ Tōhō kumiai onnatachi, Mainichi Shimbun, 4 June 1948: 5

${ }^{22}$ Tanaka Fudeko in Ishikawa 1977, 9-12. Ishikawa's two volume narrative of the strike is privately published by Ishikawa herslf. Found in the archive holdings of the Ōhara Institute for Social Research, Hōsei University.

${ }^{23}$ Ishikawa 1977, 12-20.
} 
The Tōhō experience was not isolated: the women who had organized Women's Departments within the Railway (Kokurō) and Teacher's (Nikkyōso) Unions experienced similar pressure to defer their call for gender equality and redirect their energy into supporting the family-wage and male-centered promotion structures union leaders were advocating. ${ }^{24} \mathrm{NCIU}$ officials encouraged women activists in many of the NCIU-affiliated unions to participate in ways that fit pre-war notions of women's political activism, but subordinated their economic and political interests to those of their male colleagues.

Labor leaders were resistant to addressing issues of gender equity in the workplace or the union, subjects little discussed outside the Women's Department meetings. The male-dominated leadership circles of Japan's postwar labor movement were, at best, uninterested in changing normative gender roles. Local and national unions consistently excluded women from collective bargaining agreements by making ineligible categories of employment (shortterm, temporary) commonly reserved for women; signing agreements that required "early retirement" for women who married or had children; or required round-the-clock availability for rotating shifts, which legally excluded women who were prohibited by the 1947 Labor Standards Law from engaging in "night work." Women union activists, no matter how loyal to the union, learned by hard experience that gender equality was still of very little importance to the male-dominated union. ${ }^{25}$

Women activists were likely not surprised by their union leaders' active participation in the subordination of women. Starting in the late 1940s, women writing for the national labor press published an increasing number of essays calling for union leaders to pay greater attention to women's issues. Ishikawa Masako recorded bitter memories of how in 1948 her male colleagues undermined women in the Tōhō union: recalling one union leader who had bragged to her that the previous night he had "kicked the pillow out from under the head of his sleeping wife," which he thought "confirmed his commitment to reject bourgeois liberalism. ${ }^{26}$

Nevertheless, a few Tōhō Women's Department activists expressed personal reasons for their loyalty to the union. Having started work for the Tōho company during the peak war years of the mid-1930s, clerical worker and union activist Shirota Takako recounted that in the dark days of the early post-war period "living and working conditions were as spiritually bleak as they were physically demanding." Shirota believed that the Tōhō union offered her much more than the promise of stable work and better wages: the radical politics of the union were a "clean break from the wartime experience" that offered her

\footnotetext{
${ }^{24}$ Not all women activists were waged workers, indeed women activists in the Coal and Steel Workers unions married to male union members organized themselves as Housewives Associations. See chapters 2 and 3 of Gerteis 2001.

${ }^{25}$ Mackie 2003, 120-43.

${ }^{26}$ While management certainly had not treated its employees well, a few women working at the Tōhō Studio did wonder whether the union had really repre- sented their best interests. Ishikawa 1977, 1-5.
} 
and co-workers an escape from the memory of the Tōhō Company's wartime collaboration. ${ }^{27}$

For Shirota the 1948 strike was an extension of the freedom from political repression promised by the U.S.-led Allied Occupation. As a clerical worker in the film production division, Shirota had worked most closely with directors, and by the time of the 1948 strike she knew many of them well. She asserted that while her clerical job was on its own not particularly fulfilling, her participation in the union's Women's Department and Cultural Affairs Department gave her an artistic stake in the films produced by the studio. The collective bargaining agreement won by the Tōho union in 1946 gave the union contractually equal status with management in regards to production decisions - giving Shirota, a clerical worker, a vote in determining the course of the studio's production operations. ${ }^{28}$

Significantly, the union used its contractual power to influence several key films of the post-war period, including Kurosawa Akira's No Regrets for Our Youth. Released in 1946, the film depicts the female lead Yukie, played by Tōhō star Hara Setsuko, ${ }^{29}$ as a strong-willed and defiant young woman. ${ }^{30}$ What made the film controversial at the time was not that the union significantly influenced the film's production, but that No Regrets was the first post-war Japanese film to feature a strong female character in the leading role. ${ }^{31}$

Released less than a year after war's end, the film was especially popular among young women, who felt drawn to Hara Setsuko's portrayal of Yukie. ${ }^{32}$

\footnotetext{
${ }^{27}$ The Tōhō Company was responsible for many of the feature films used to promote wartime state policies and obscure the exploitative nature of Japan's relationships with China and Korea. For a more complete account of the Tōhō Company's wartime collaboration, see Hirano 1994. Tanaka Fudeko discusses her wartime experiences at Tōhō in Ishikawa 1977, 3-7.

${ }^{28}$ Ishikawa 1977, 7-15.

${ }^{29}$ Because of her wartime popularity, Hara is often thought of as a "poster girl" of Japan's wartime government. In the early post-war years, however, political expediency led many wartime artists, such as Hara, to flit along the borders of leftist organizations like the Tōhō union. In her later years Hara condemned the union for being too politicized.

${ }^{30}$ Kurosawa later complained that he had been forced to accept the Scenario Review Committee's version of the last twenty minutes of the film, which he believed had been distorted by the union's Communist agenda. Indeed, Kurosawa asserted that he had "poured all his rage at the Scenario Review Committee into those final scenes." See Kurosawa 1982, 166-67.

${ }^{31}$ During the first two and a half years of the Occupation, "freedom of expres- sion," "gender equality," and "democracy" were the stated aims of the social and political reforms initiated by the Allied Occupation, and chief of the Civil Information and Education Section David Conde had urged Kurosawa to make No Regrets into a vehicle for promoting the Occupation's social agenda. See Hirano 1994, 179-204.

${ }^{32}$ Hara Setsuko stopped making films after the death of favored director Ozu Yasujiro in 1963. Donald Richie observes that Hara is remembered in Japan as an "enigmatic character oddly separate, and inseparable, from her film roles. This was because on the screen she reconciled her life as real people can- not....Truly, in that
} 
After her father's death, and the imprisonment of her lover, Yukie begins a journey of self-discovery that takes her from the emptiness of bourgeois "city life" to a "life without regrets" laboring in the countryside, unmarried and without children, alongside the parents of her dead lover. Critics did not receive No Regrets well: many hated Hara's portrayal of a character they believed "too selfish," arguing that the film was unrealistic in the way it portrayed Yukie's choice of a life outside the accepted norm. ${ }^{33}$

Hara also disliked the film - nearly as much as she despised the union who she believed dictated its making. She later confided that her experience making No Regrets had convinced her to quit both the Tōho union and the studio. In mid1947, Hara and eleven other actors and actresses resigned from the union's closed shop at Tōhō in order to join a spin-off studio named, rather unimaginatively, New Tōhō (Shin Tōhō). Managers with the original Tōhō studio were consequently forced to hire a new stable of actresses, and in a cheap attempt to retain some of the "star power" of the departed Hara Setsuko, company mangers even renamed one of the new actresses "Hara Sadako." ${ }^{34}$

Hara Setsuko's departure greatly weakened studio and union, and Shirota Takako, who remained in the union and employed at the original Tōhō Studio, recalled that the "dream-like quality of union life began to crumble" when "the radical politics of the union split the company into two." ${ }^{\prime 35}$ Director Akira Kurosawa also chose to stay with the original Tōhō Studio, but later said that he had resented how a small group of Communist union leaders had pressured him to end No Regrets with Yukie choosing to live a life toiling at heavy farm labor. ${ }^{36}$

The political fallout over the film damaged the union's popular image, and the film had negligible propaganda value. The head of the Motion Picture Division at GHQ, David Conde, had suggested the film to Kurosawa as a means to promote women's rights and democratization, and the union had pressured Kurosawa to end it with a stolid nod to socialist iconographies of self-sacrifice. It seems odd that critics perceived Yukie's selfless labor alongside her ersatz parents-in-law as "too selfish" - only her lover's untimely death (which negated any chance for marriage) seems to have kept this from depicting precisely the kind of patrilineal relationship that David Conde, whose job was to

though she played all social roles - daughter, wife, and mother - she only played them in her films. They were inventions and did not eclipse the individual self of Hara Setsuko. And in this way she exposed the so- cial roles of women in film for the fictions that they are." Hara never married; she never bore children, nor maintained obvious romantic connections with men. Her primary relationships were entirely with women, and her life was not reconcilable with the model of womanhood portrayed in her films. Hara refused to embody their desires off screen. See Richie 1988.

\footnotetext{
33 Katogawa 1947, 29-33; and Tōgō 1946, 26-27.

${ }^{34}$ Hirano 1994.

${ }^{35}$ Ishikawa 1977, 3-15.

${ }^{36}$ Ibid.
} 
convince Japanese filmmakers to make films that promoted the Allied Occupation's social agenda, had intended the film to subvert. The mode of socialist self-sacrifice portrayed by Yukie was disturbingly similar to the customary role a married woman would have played in Japan's traditional family system.

By the time of the 1948 strike No Regrets was long completed, and Hara long gone, but the creative tensions between union and artists had not receded. Union leaders had intended to continue production through the 1948 strike, but supplies of film stock were tightly controlled by Occupation authorities, and strikers were unable to scrounge enough to complete even a short documentary about their strike, much less a major motion picture. Fumio Kamei's Life of a Woman (Onna no isshō) was among the films in progress when the strike began, and was the first completed when the strike was settled in the autumn of

1948. Based on the acclaimed novel Hitoridachi, by communist Tokunaga Sunao, Kamei's Life of a Woman (released in January 1949) was the first motion picture completed under the strike settlement that had been reached with management the previous autumn. In a rare concession, management had agreed to allocate 15 million yen from the film's profits for the union's strike settlement fund. ${ }^{37}$

Kamei, under tremendous pressure from the union to make the film a commercial success, nevertheless created a stunning social critique that did not play well at the box office. The film depicts the life of the protagonist Akiko as she tries to navigate the complex circumstances of post-war life. In the film, economic hardship and family pressure force Akiko, played by Tōhō newcomer Mizuki Yōko, to continue work as a typesetter even after her marriage to her lover Shphei (Yasumi Toshio). Despite a dominating mother-in-law and weak husband, Akiko does her best to fulfill her customary obligations by using her wages to support both her marital and paternal families. Even after becoming pregnant, and despite abuse by her mother-in-law and working conditions that erode her health and endanger that of her unborn child, Akiko continues working in order to meet her twofold familial obligations. The film ends in crescendo with a repentant Shphei, ashamed of having allowed his wife to endure such abject conditions, leading the typesetters in a strike for wages and working conditions that better suited the needs of their families. Neither Conde nor Kamei appear to have perceived the irony in Shphei's redemption coming through a strike settlement that emphasized the family as the fundamental unit of society.

Kamei appears to have been serving several creative masters with this film. Certainly, the financial arrangement between the union and the studio company must have been pressing him to produce a commercial success - and he even included a "kissing scene," which was a known box-office draw, but also encouraged by David Conde, who thought "on-screen kissing" symbolic of the democratic reforms mandated by the Allied Occupation. Film critics, however, described Life of a Woman as an expression of the anger Kamei had

\footnotetext{
${ }^{37}$ Miyamori 2002, 153-57.
} 
felt toward the traditional family structure. Akiko's adverse life circumstances, dedication to an abusive extended family, and competence in her work as a typesetter allow the viewer to perceive her as a strong and sympathetic character who should be at odds with the social system to which she was enslaved. ${ }^{38}$ Union leaders might have been proud of the film's biting critique of the double bind working women endured, but Shphei's redemption still depicted the family as the fundamental unit of society. Even so, the film's failure at the box office, which resulted in a financial loss for both the company and the union, accentuated animosity toward Kamei who was accused of privileging his political and artistic independence at the cost of the film's commercial success. ${ }^{39}$

\section{Suppression}

Tōhō clerical worker and union activist Shirota Takako recalled that it was like "stepping into one of the war movies Tōhō had made before the surrender" when on the morning of 19 August 1948 U.S. tanks accompanied by nearly two thousand Japanese police moved into position around the Tōhō Kinuta Studio. ${ }^{40}$ With U.S. tanks, infantry, and riot police massed at the barricaded studio gates, ${ }^{41} \mathrm{NCIU}$ leaders advised the striking film workers to comply with an eviction order served by the Tokyo District Court. In a last minute deal, company president Watanabe agreed to renew contract negotiations with the union if they left the studio. Facing overwhelming force, the striking film workers had little choice but to comply with the ultimatum. Within a few minutes they had assembled their parade, and sang the "Internationale" as they marched out the back gate, waving a red flag and carrying banners that decried the destruction of Japanese culture. Several accounts of that day also recall that the Tōhō actresses wept as they marched. ${ }^{42}$

\footnotetext{
${ }^{38}$ Ibid.

${ }^{39}$ Kamei was forced to quit the Tōhō Studios in mid 1949, ostensibly so he could produce independent "pro-democracy" films.

${ }^{40}$ Miyamori 2002, 153-57.

${ }^{41}$ On a platform above the gate, stationed next to a large studio fan, several Tōhō strikers stood poised to spray the police with what military intelligence later reported to be broken glass, but what was most likely blue or red paint. Mili- tary Intelligence reported to Washington the following day that the strikers planned to spray the troops with glass and sand, but Nichieien leaders later in- sisted that they only intended to symbolically mark the police as oppressors of the working classes by spraying them with red paint. The plan to use red paint was changed to blue because some strikers thought the obvious reference to the blood of the working class might enrage the police. Military Intelligence Section, General Staff, "Intelligence Summary," 19-21 August 1948. No. 2187, (RG6, Box 39), MacArthur Archives, Norfolk, Va.

${ }^{42}$ Weeping actresses specifically identified by Asahi Shimbun included Hara Sadako, Kuga Yoshiko, Kei Ranko, and Wakayama Setsuko. Asahi Shimbun, "Tōhō kumiai: kinuta satsuenjō akewatashi," 20 August 1948: 2; J. Lambert, "Kinuta Strikers," Nippon Times, 20 August 1948: 1; and Roundtable 1971, 164-91.
} 
The events of that day made national headlines, closely monitored by American censorship officers who would not allow the publication of any reports about U.S. supervision of the suppression of the Tōho strike. ${ }^{43}$ Deciding to exit the studio was not easy for Shirota Takako, who recalled that some strikers had argued instead for the union to provoke the authorities into bloodshed. She was relieved, however, when cooler heads prevailed and the strikers voted to vacate. Nevertheless, she asserted that the tenor was by no means one of abject defeat. Indeed, Shirota recalled that it was with a sense of dignity that she joined the other members of the Tōhō Women's Department in parading out the studio gate - remembering with pride that director Fumio Kamei wore a placard that declared "Culture will not be destroyed by Arms or Violence." ${ }^{44}$

Women's Department activist, and later department chief, Ishikawa Masako also recalled the union's final march out the studio gates in romantic detail. While both Ishikawa and Shirota agreed that they marched and sang with dignity and pride, neither remembered weeping. This is odd, because the women's weeping featured prominently in other accounts, men's accounts, of the strike. ${ }^{45}$ Odd too is that many popular and scholarly accounts describe the Tōhō Women's final march out of the studio gates, but rarely mention the extent to which women participated in the strike itself. Indeed, many of these narratives seem to fantasize about how on 19 August the Tōhō actresses wept, and it is possible that Tōhō's militant women were most useful when remembered as engendering the arrival of U.S. hegemony in Japan. ${ }^{46}$

It is also significant that the men and the women present that day seem to recall events differently - men remember women crying but the women do not recall themselves as having cried. The trouble here goes far beyond the fact that memories are notoriously unreliable and that we can likely never establish as fact whether or not the Tōhō women staged what film scholar Donald Richie characterizes as a "cry-in." ${ }^{47}$ The discordance between personal and official memory points to a larger problem: women unionists were represented by men as having portrayed women as men preferred to see them. Unfortunately, the problem was endemic to the labor movement, which is perhaps most evident in the ancillary propaganda distributed by the Tōhō union and its affiliate organizations.

\footnotetext{
${ }^{43}$ Ishikawa 1977, 3-15.

${ }^{44}$ Ibid.

${ }^{45}$ In the 1971 Gendai to Shisō roundtable discussion, producer/director Itō Takeo and film critic Yamamoto Satsuo recalled that the Tōhō women cried as they marched, while labor scholar Shiota Shiyōbe described the Tōhō women's weeping as a demonstration. Donald Richie writes that a "contingent of Tōhō actresses put on a crying act...and were...followed by a cluster of un- furled red flags with everyone singing 'The Internationale.'" Roundtable 1971,164-91; and Anderson and Richie 1982, 171.

${ }^{46}$ Indeed, the Tōhō women's "cry-in" made quite an impact; it featured prominently thirty-five years later in film scholar Donald Richie's brief account of the strike. Anderson and Richie 1982, 171.

${ }^{47}$ Ibid.
} 


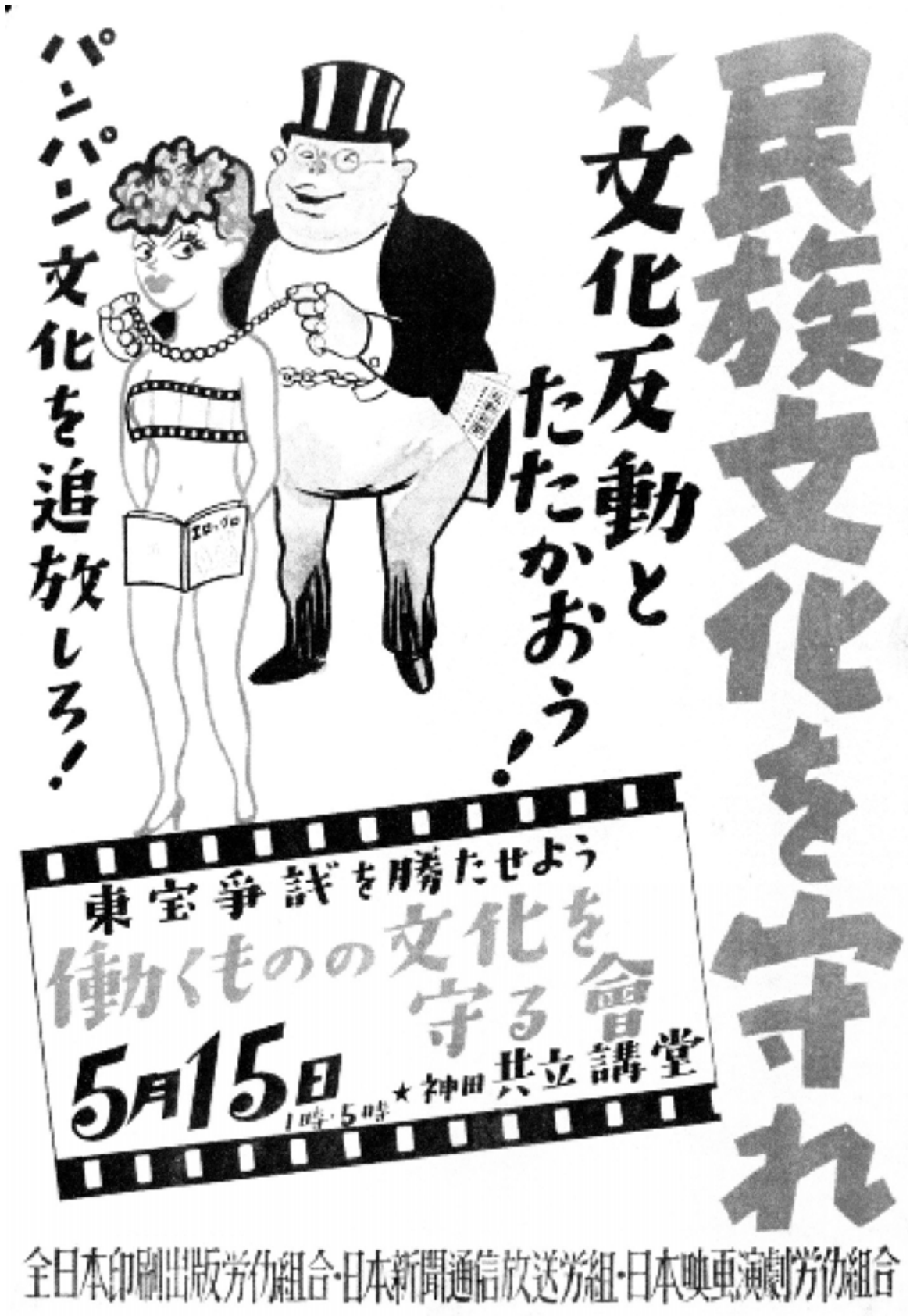

Figure 1. Far right, from top to bottom: "Defend the National Culture!" Far left, from top to bottom: "Banish the Culture of Whores!" 38cm x 54cm. PB0169: 15 May 1948. (Digital image courtesy of the Ōhara Institute for Social Research, Tokyo.)

\section{Gendering the Nation}

Visual propaganda produced in support of the Tōhō Strikers played a significant role in the union's attempt to garner popular opinion. The poster depicted in figure 1, designed to mimic a commercial art poster that would have announced the release of a new motion picture, invokes a nationalist discourse that stems from the Leninist validation of nationalist movements that presaged 
socialist revolution. ${ }^{48}$ In the poster, a heavyset man wearing a top hat and coattails is fastening a string of pearls around the neck of a young woman, her breasts concealed by a length of film stock and her pubis covered by a film script. The male figure is an obvious representation of the "fat capitalist," while the female figure represents both the film industry and the Japanese nation. The first slogan, in large red text, calls on the reader to "Defend the National Culture!" (Minzoku bunka wo mamore!), and the middle slogans declare that the struggle at Tōhō is to support the producers of Japanese culture (minzoku bunka) in their fight against the imposition of reactionary culture (handō bunka) threatened by capitalist dominance of the film industry. Taken as a whole, the poster tells us that the Tōhō strikers were simultaneously the producers and defenders of Japan's national culture in the face of the Allied Occupation's domination of the film industry.

Minzoku, which I first introduced here as "nation," is commonly translated as "race." The term has a deeply troubled history that in the context of the Tōho Strike makes "ethnic-nation" the more accurate translation. ${ }^{49}$ Kevin Doak observes that "the problem of national identity in Japan and citizenship in modern Japan was shaped to a considerable degree by the historical formation of populist attitudes in the early twentieth century that were quite hostile to the new Meiji state." Despite disparate beginnings, popular and elite representations of the political nation had by the mid-1920s converged on the idea that Japan was an "ethnic nation" (minzoku) with racial as well as political ties. By the 1930s, Japanese nationalists who "recognized the element of race in the nation...also drew attention to the usual litany of 'cultural' elements that nation implied (shared territory, spirit, language, religion, and customs)."

The wartime state was, in the late 1930s and early 1940s, able to appropriate popular conceptions of the minzoku, and interweave them into the political fabric of its imperial and colonial projects. Doak does not claim an absolute continuity between pre-war and post-war discourses. He argues instead that "the

1950s were the formative period in the rehabilitation of ethnic nationalism among leftist critics of the Japanese state," and he locates the critical juncture within leftist debates that took place in the early 1950s. The anti-communist backlash that followed in the wake of the North Korean invasion of the South encouraged many leftists to revisit ethnic nationalism, but this time "ethnic nationalism was seen as an effective tool for criticizing, simultaneously, the capitalist post-war Japanese state and the cultural colonialism of U.S. imperialism." ${ }^{51}$

In the wake of the wartime state's rhetoric of colonial assimilation, some leftists advocated an ethnic-national, anti-imperialist discourse - believing it a viable alternative to the bourgeois democracy made compulsory by the U.S.

\footnotetext{
${ }^{48}$ Lenin, V.I. The socialist revolution and the right of nations to self-determina- tion. In Lenin 1970, 143-56.

${ }^{49}$ See Doak 1997, 283-309.

${ }^{50} \mathrm{Ibid}$.

${ }^{51} \mathrm{lbid}$.
} 
occupier and its collaborators. Curtis Gayle argues that a significant minority of Japan's post-war Marxists cited anticolonial movements in India and China as evidence that a true Asian modernity lay in an ethnic-nation, differentiated from state, capital, and empire, united in resistance to the West. Victor Koschmann rightly questions the audacity of the Japanese, only recently deposed as imperial and colonial aggressor, laying claim to status as a victim of U.S. imperial hegemony. Nevertheless, Gayle in part argues that the legacy of wartime rhetoric on ethnic commonality (that underpinned forced assimilations in Taiwan and Korea) may have combined with the narrowing of ethnic identification that accompanied the American post-war bifurcation of Japan and Korea to provide fertile soil for the belief that the West was the true hegemonic threat. ${ }^{52}$

The propaganda developed for the Tōhō Strike exhibits a leftist rehabilitation of the minzoku that parallels that described by Gayle and Doak. In this context, the first slogan in figure 1 calls for the defense of the "ethnic-national culture" (minzoku bunka) in what was clearly an appeal to protect Japan from U.S. cultural hegemony. ${ }^{53}$ However, U.S. military officers reacted badly to the poster probably because the slogan to the far left called on the ethnic-nation to "Banish the Culture of Whores!" (Pan-pan bunka wo tsuihō shiro!). In the context of the strike, the slogan accuses Tōho management of treating film workers like prostitutes, but also suggests that the capitalist-dominated film industry serviced the Allied Occupation in the way that teenage prostitutes (pan-pan girls) serviced Allied soldiers in the streets of Osaka and Tokyo.

By illustrating the pan-pan girl as she accepts a presumably expensive string of pearls from the hands of the fat capitalist, the pan-pan girl in figure 1, her breasts and pubis covered by the material components of film work, signifies an exploited and victimized nation. The image serves to rally the nation by portraying a titillating female body under the threat of class exploitation and moral corruption. Simultaneously, the slogan "banish the culture of whores" invokes for readers the threat posed by the Allied occupiers whom the real-life pan-pan girls serviced.

A complex history further informs the anti-imperialist context of the pan-pan deployed in the Tōhō poster. Both decolonization and anti-imperialist discourses are deeply gendered tropes of nationalist rhetoric that, as Elaine Kim and Chungmoo Choi argue, reclaim "masculinity at the expense of women and its interest in sexuality. ${ }^{154}$ The use of the sexualized female form to portray the nation in jeopardy is not new; visual propaganda that uses women's bodies to signify larger political issues has historically been quite useful in conveying

\footnotetext{
${ }^{52}$ Morris-Suzuki 1998, 87; Gayle 2002; and Koschmann 2005.

${ }^{53}$ And invokes a nationalist discourse stemming from the JCP's switch to anti-imperialist rhetoric that accompanied the Cominform's 1947 rehabilitation of the Stalinist validation of ethnic nationalist revolutions. Stalin, J.V. Marxism and the national question. In Stalin 1955. See Gayle 2002.

${ }^{54}$ Kim and Choi 1998, 5.
} 
many kinds of nationalist discourses, from Nazi Germany to wartime America, in part because the state seldom afforded women a public voice of their own. ${ }^{55}$

The invocation of the debased status of a working-class prostitute as a means to symbolize capitalist exploitation of the industrial proletariat also carries over from the pre-war Japanese socialist movement, which had used images of women in subservient and debased relationships to the "fat capitalist" to communicate the threat posed to the nation by domestic capitalist hegemony. Pre- war leftists first developed visual propaganda, from posters to political cartoons, in order to reach illiterate workers who union leadership believed, in the Marxist lexicon of the era, to be yet unable to perceive the objective nature of their oppression. Vera Mackie argues in part that images of women, prostitutes in particular, were an important part of pre-war socialist iconography and were intended to create a socialist subjectivity within which workers could reimagine their political subjectivity. ${ }^{56}$

The post-war Communist Party critique of the Occupation partially reemployed the pre-war discourse when referring to the Japanese government as a pan-pan seifu, or "government of whores." While the labor press reflects a strong ideological bent in step with that of the JCP, no records survived that prove that Tōho union leaders were working with the Communist Party when they created these posters. ${ }^{57}$ Nevertheless, the pan-pan depicted by the Tōho union is much more than a rehabilitated pre-war discourse on class exploitation. It is a double-voiced signifier of the simultaneous class and cultural exploitation specifically endured under the American-led Allied Occupation. ${ }^{58}$

What makes this deployment of the pan-pan particularly problematic is that folk etymology locates the origins of the term with Japanese soldiers who had coined the expression to describe how they clapped their hands twice to call for the prostitutes working near military bases in China, Korea, and Southeast Asia. ${ }^{59}$ The majority of military base prostitutes were non-Japanese colonial subjects, ethnic Korean and Okinawan women; all were from the lower classes, and a disturbing number also served against their will. ${ }^{60}$ The tragic history of

\footnotetext{
${ }^{55}$ Indeed, "women" conjured by, and for, the male gaze in Germany, the Soviet Union, and the United States were also useful to a variety of male-dominated institutions outside the state, from political parties to labor unions, and these organizations relegated women to the role of discursive representation rather than political agent. The most famous pieces of visual culture of this type were the American pin-up girls commonly seen on everything from magazine covers to aircraft noses during World War II.

${ }^{56}$ Vera Mackie, in Creating Socialist Women, was the first to analyze the trope of the "prostitute" in the labor propaganda of pre-war Japan. My discussion of sex work is most influenced by Brewis and Linstead 2000; Chapkis and Sprinkle 1997; Delacosta 1998; Diamond and Quinby 1998; and Johnston 2002.

${ }^{57}$ Collected Papers of the Sanbetsu Kaigi, held by the Ōhara Institute for Social Research, Hōsei University.

${ }^{58}$ This poster may have made GHQ far more conscious of the anti-American, anticolonial context of union discourse than of its communist ideology.

${ }^{59}$ Takeuchi 2001, 36-56; and Sanders 2005, 126.

${ }^{60}$ Hicks 1997; and Tanaka 2002.
} 
these women's lives underscores the significance of the problem. Leftist artists and intellectuals uncritically positioned a term, likely coined to describe the colonial women who serviced Japanese soldiers and then re-deployed to chastise young women who sold sexual services to American soldiers, in order to describe what men on the political left perceived as their exclusion from a meaningful role in the post-war regime. In short, the redeployment of the panpan gave political voice to men, who perceived themselves as subaltern subjects, by stripping Japanese women (as the engendered nation) and denying colonial women (as the ethnicized "other") their voices. ${ }^{61}$

Allied Occupation officials also had, at best, a difficult relationship with the issue of interracial sex, and prostitution in particular. Prostitution was not new to Japan, however, the "pan-pan girls" referred to in figure 1 were women who worked on the fringes of an industry specifically to service Allied troops. ${ }^{62}$ Prior to the arrival of Allied soldiers in August 1945, the Japanese government had circulated calls for community leaders to recruit young, lower-class women who would serve as prostitutes for Allied soldiers. Local government leaders organized "comfort stations," in part modeled on the system of brothels developed by the Imperial Army in China and Southeast Asia, where U.S. personnel would be directed for sexual services. The idea was to maintain racial hygiene by isolating what Japanese government officials and community leaders believed were the unavoidable sexual needs of a conquering army. ${ }^{63}$

GHQ officially banned sexual fraternization, and at first threatened harsh punishment and court-martial for military personnel who openly dated or married Japanese women. Nevertheless, GHQ officers pragmatically ignored their soldiers' use of prostitutes. Although GHQ was embarrassed into closing the official brothels less than a year after their creation, a regular supply of young, destitute, often homeless girls assumed the role of servicing the Allied soldiers whom regular, higher-class prostitutes would not. The popular press gave these girls, despised as the social scourge of the cities, a label popularly thought to describe the colonial women who had serviced Japanese troops during the war - pan-pan. ${ }^{64}$ Even as they had banned sexual fraternization, Japanese and Allied officials cooperated to informally encourage, and even regulate, the pan-pan industry as a means to defuse the threat that interracial marriage, not sex, posed to their mutually segregated societies. ${ }^{65}$

\footnotetext{
${ }^{61}$ Gramsci 1992; and Gramsci 1967.

${ }^{62}$ See Dower 1999, 124-32.

${ }^{63}$ Takeuchi 2001, 36-56; and Sanders 2005, 80-98.

${ }^{64}$ Yuki Fujime (2006) argues that there were considerable differences in sexual fraternization policies between British and U.S. forces, and even enforcement practices varied by region. However, the Tokyo region was a U.S.-dominated

${ }^{65} \mathrm{~A}$ concern made all the more significant by the JCP's shift to an anti-imperialist critique in 1947. Nevertheless, many Americans believed Japan to be especially tolerant of female sex work, and as a result some of the more moralistic authorities spent considerable time and effort trying to discourage soldiers from engaging in the various services on offer. Under considerable pressure from Washington to ban prostitution in Japan, GHQ ordered the Public Opinion and Statistical Research Section to conduct a survey of popular attitudes to- ward
} 
In an odd twist of events, race may have factored into the U.S. decision to suppress the strike at Tōhō. Indeed, the "fat capitalist" and the "pan-pan" depicted in the Tōhō poster (figure 1) may have appeared "American" to GHQ officials. The U.S. military high command was intensely sensitive to the fact that Truman was about to order the military to desegregate, and the perceived accusation that the U.S.-dominated Allied Occupation was perpetrating a "Culture of Whores" on the Japanese ethnic-nation (minzoku) may have been perceived as a racial attack on the legitimacy of the Allied Occupation. ${ }^{66}$ At a Labor Division debriefing held at GHQ on 20 August, Colonel Frank Hollingshead, commander of the Tokyo Military Government Team, claimed that a member of General Douglas MacArthur's general staff, most likely Major General Courtney Whitney, had complained to him about the Tōhō propaganda in early August, which zone, and there is little doubt that Tōhō critique was aimed at the Americans.

Hollingshead interpreted as an order to suppress the strike "by whatever means necessary." ${ }^{167}$

prostitution with the hopes that the Japanese government could then be pressured to make it illegal. U.S. survey teams constructed interview schedules with the assistance of their sibling bureau in the Prime Minister's Office of the Japanese government. Anthropologist John Bennett later recalled that the re- sults of the survey indicated that while many women were critical of prostitu- tion and resented men using the facilities, men were much less concerned with the issue to the point of even wondering why anyone was asking these questions in the first place. Oddly, the survey submitted to GHQ concluded that there was "no strong feeling in either gender that prostitution was a grave moral issue" and suggested that the "Japanese people, lacking a strict universal religious morality, tended to judge things as good or bad depending on situa- tions and consequences." See Bennett 2002; and Molasky 1999.

${ }^{66} \mathrm{GHQ}$ had also recently implemented a general crackdown on ethnic Koreans demanding the rights of citizenship in Occupied Japan. GHQ's denial of voting rights for Korean residents, closure of ethnic-Korean schools, and involuntary repatriation of thousands of militant Korean mine workers caused consider- able ethnic discord between GHQ and resident Koreans. Ironically, the official reasoning behind the U.S. suppression of Korean institutions and organiza- tions was that they caused social discord by encouraging ethnic segregation. However, GHQ initiated the crackdown on Japan's resident Korean commu- nity in part because the status of ethnic Koreans in Japan (many of whom had spent the colonial years in ersatz slavery) mirrored the U.S. military's own om- nipresent "Negro Question" by militantly demanding equal treatment under the law. On the history of the status of Korean residents during the Occupa- tion, see Takemae 2002, 452-54; and Ricketts 1995. For a brief overview of the status of African-American soldiers in the immediate post-war period, see Smith, Krawczynski, and Jefferson 2002.

${ }^{67}$ Under orders to resolve the situation, Hollingshead met with unnamed police officials, a district court judge, and Tōhō lawyers on the morning of 18 August. Hollingshead strongly suggested to the company lawyers that they request po- lice assistance in evicting the strikers from the studio. When police officials objected that only a court representative could make such a request, Hol- lingshead 
The pan-pan depicted in figure 1 operated as part of a marginalized discourse railing against class and cultural domination. The pan-pan also reflects the attitudes of more dominant social groups (such as capitalists) toward women. By deploying the pan-pan as an icon of race/class domination, the Tōhō union may have acquiesced in, at tremendous cost for women, a conceptual framework from which marginalized men could find common ground with their social peers as well as claim political ground against their oppressors. ${ }^{68}$

The "woman" portrayed in figure 1 is decidedly not an agent of her own destiny, but a representative of a male fantasy/fear of domination at the hands of an oppressor class/nation and is used by propagandists to signify the union's championing of the Japanese ethnic-nation at the cost of suppressing women's political subjectivity and eliciting U.S. suppression.

\section{Boogie Nights and Cross-dressed Politicians}

The propaganda deployed in support of the 1948 strike at the Tōhō studios is only one example of how union-affiliated artists used gendered imagery to exemplify their political agenda. During the period that preceded the U.S. crackdown on union militancy in August 1948, several high-profile labor cartoonists were also engaged in significant visual propaganda campaigns. By far the most interesting images were those by political cartoonist Katō Etsurō, who drew for both politically moderate and left-leaning organs of the national labor press throughout the Occupation period. In the summer of 1948, he was engaged in an overt attack on the policies of the Ashida government that culminated with a series of cartoons that also attacked the legitimacy of U.S. hegemony in Occupied Japan.

Like most cartoonists of his era, Katō Etsurō exhibited a high degree of ideological flexibility, which saw him rapidly abandon the militarist propaganda he had produced during the war and join master cartoonist Kondō Hidezō in producing pro-Occupation propaganda for the comic magazines Manga and VAN. A survivor of the ideological witch-hunts of the wartime era, and well aware that U.S. censors stood poised to cut any direct attacks on the Emperor, MacArthur, or the Allied Occupation forces, Katō avoided direct censorship of

suggested to the district court judge that he make the request. At first, the judge refused the colonel's order, but Hollingshead persisted, and af- ter considerable bluster the judge reluctantly complied and ordered the police to evict the strikers. That night, a platoon of U.S. soldiers of the First Cavalry Di- vision and five Sherman tanks and two armored cars from the Eighth Army were recalled from combat maneuvers around the Mt. Fuji area and ordered to the Kinuta neighborhood of Setagaya Ward. At Camp Drake, outside Tokyo, a company of U.S. soldiers was also put on one-hour ready alert. ESS, Labor Divi- sion, Labor Relations Branch, "Memorandum of Conference: re. Tōhō Movie Studios Dispute," August 20, 1948. Chronological Files, May 48-December 48 (RG331, Box 8477, Folder 9), National Archives at College Park; and Lambert. Kinuta Strikers, Nippon Times, 20 August 1948: 1.

${ }^{68}$ Heineman 1999. 
his artwork in part by directing his sarcastic wit at nearly every other actor on the national political stage. ${ }^{69}$

Katō's artistic relationship with the labor movement began in early 1946. After contributing to several labor magazines, including the militantly leftist organ of the Japan Railway Workers' Union, Kokutetsu Bunka, Katō began in mid-1948 to draw for the politically moderate Dōmei Comic News. ${ }^{70}$ Published by the General Federation of Trade Unions (GFTU, or Sōdōmei), archrival of the Communist-led NCIU (of which the Tōhō union was a member), the Comic News was designed to reach an audience generally thought to be comprised of politically moderate union members who, although not strong readers, nevertheless understood the significance of the political moment of which they were a part.

Not long after Katō began contributing to the Comic News, the GFTU became embroiled in the conflict over a directive from GHQ that recommended that the Ashida Government strip public sector workers of many of the union rights to that point guaranteed by the legal reforms mandated by the Allied Occupation. $^{71}$

\footnotetext{
${ }^{69}$ Sodei and Dower 1988. In Burkman 1988, 93-124; and Katō 1960.

${ }^{70}$ Fewer than a dozen panels identified as drawn by Katō for the GFTU's Comic News have survived.

${ }^{71}$ On 24 July, MacArthur issued a directive to the Japanese government that declared that "no person in public service should resort to strikes or other dispute tactics detrimental to the efficiency of governmental operations." Labor Division chief James Killen responded to MacArthur's directive by discontinuing all official contact with public sector unions, explaining that "until clarification is secured as to which agency of [the Occupation] is responsible for labor conditions affecting government workers, it will be impossible for this [Labor Division] to effectively advise either the unions or the Japanese Government." In effect, Killen interpreted MacArthur's memorandum as the revocation of the constitutional right of public sector workers to be represented by their unions. MacArthur had been advised that revoking union rights for the public sector would be the first step toward breaking communist leadership of the labor movement. Economic advisor Blaine Hoover argued that Japanese workers at large public enterprises, such as Japan National Rail, should lose their right to strike, but retain their right to bargain collectively, while civil service workers in Japan, including teachers, should lose both. Douglas MacArthur called Hoover and Labor Division Chief James Killen into his office to argue the plan in front of him. Killen vehemently opposed Hoover's plan and argued that the plan threatened to "destroy...or at least effectively dilute many of the more liberal aspects of the Occupation." Killen to Burke, 15 July 1948, IBSPMW Papers cited by Schonberger 1989, 125; and "MacArthur Urges Law to Prohibit Walkouts by GovernmentWorkers," Nippon Times, 24 July 1948: 1. ESS, Labor Divi sion, "Memorandum for the Record," 24 July 1948, Chronological Files, May 48-Dec 48, (RG331, Box 8477, Folder 9), NARA.
} 
The Ashida Government interpreted the directive as an order to curtail union militancy and on 25 July banned all public workers from engaging in walkouts or strikes. ${ }^{72}$ Although NClU-affiliated unions were the primary targets of the public sector strike ban, leaders of the GFTU also perceived the ban as antilabor, and chose to make this the central issue of a national propaganda campaign within which the Comic News, and Katō Etsurō, would play a significant role.

Just one week prior to MacArthur's decision to ban public sector strikes, and two months into the siege at the Tōhō studios, the Comic News published a panel by Katō (figure 2) that featured a bare-chested, burly, male worker wearing "army green" fatigues, cap, and work boots. Katō depicted the overtly masculine form pumping insecticide onto a dustbin (an obvious allusion to the "vileness" of the brothels that seemed to thrive during the Occupation) from which a dozen nude and partially clothed, bug-sized men and women scramble to get away. Katō has labeled the spray pump as containing an insecticide made of "Working-man's Culture," and the burly man appears to be spraying the "insecticide" in order to eradicate the "Reactionary Erotic/Grotesque Culture" scrawled across the lid of the dustbin/brothel. While the male form could be seen as an American GI, and whatever the implied content of the rather phalliclooking spray pump, ${ }^{73}$ Katō appears to have not positioned this panel as a critique of the Allied role in the sex industry; rather, he seems to be asserting that willful participants in the "culture of sex" (ero guro, the erotic grotesquerie) were the "maggots that hinder[ed] Japan's democratic culture."

Katō also had a history of lampooning his peers, and it is possible that he meant this panel to be a simultaneous criticism of the popularity and apolitical character of the "ero-guro" cartooning that had become an all-too-comfortable way for many cartoonists to make a living. Additionally, it seems possible that Katō meant this as an overt moral indictment of the liberal bourgeois, whose patronage of the "erotic grotesque culture" he believed had defiled the nation (the basis of the critique made in figure 2). Unfortunately, because Katō left no memoirs or interviews about his artwork, we will likely never know for certain what Katō intended to convey in this panel. The record of his political cartooning from the remainder of that summer, however, does indicate that he was about to make a significant shift in rhetorical strategy. ${ }^{74}$

\footnotetext{
${ }^{72}$ In the furor that followed, both Killen and Richard Deverall resigned from the Labor Division, and accused GHQ of treating the whole of organized labor in Japan as part-and-parcel of Soviet communism. The two returned to the United States and proclaimed the alliance between state and labor in Japan a complete failure, and at their urging the American Federation of Labor passed a resolution calling on the U.S. government to rescind MacArthur's "reaction- ary revision of the labor law in Japan." See Schonberger 1989, 125.

${ }^{73}$ The precise nature of the "working man's culture" is left to the reader's imagination, but given the physical stance of the male figure, and phallic form of the bug sprayer, the reader could easily conclude that this "Working-man's Cul- ture" was indeed seminal.

${ }^{74}$ For a brief discussion of Katō, see Sodei and Dower 1988. In Burkman 1988,93124.
} 
A few weeks after his condemnation of the "erotic grotesquerie," Katō launched a full-scale attack on the government of Prime Minister Ashida Hitoshi.

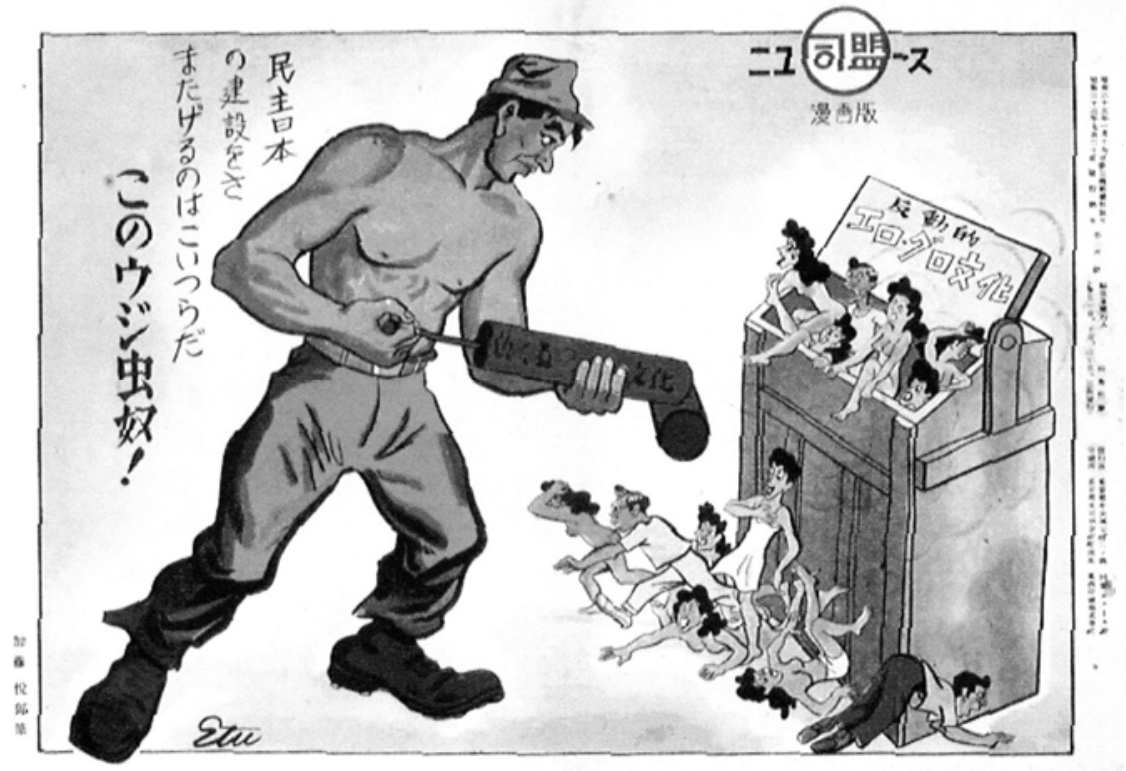

Figure 2. Trash bin (far right): "Reactionary Erotic/Grotesque Culture." Far left (beside large masculine figure): "These maggots hinder[ed] Japan's democratic culture!" Katō Etsurō, Dōmei nypzu mangahan dai nijp ban, 36cm x 26cm, PB0806: 20 July 1948. (Digital image courtesy of the Ōhara Institute for Social Research, Tokyo.)

The panel reproduced in figure 3 (below) is split into four scenes in which Katō appropriates an American song (made popular in the nightclubs of Tokyo) to accuse the ostensibly moderate Ashida Government of being no different from that of its conservative predecessor, Yoshida Shigeru. ${ }^{75}$ The text of the panel, sung to the tune of the Andrews Sisters' "Boogie Woogie Bugle Boy":

While the Boogie Woogie plays, jobs are lost (kubikiri), Erotic Dawn; Erotic Dusk: [this is the] Cultural Nation (bunka kokka), A Peaceful Nation (heiwa kokka), the black market [thrives], Ashida, Yoshida - only the letters (kanji) are different. ${ }^{76}$

The first scene (associated with line 1 of the text quoted above) portrays a man and a woman wildly dancing to the line "while the Boogie Woogie plays, jobs are lost," as the man's head flies from his neck. The second scene shows a partially nude, large-breasted woman, her pubis covered by a fig leaf, dancing to the lyric.

\footnotetext{
${ }^{75}$ The moderate conservative Ashida Government (March-October 1948) was immediately preceded by the short-lived Socialist Government of Katayama Tetsu (May 1947-March 1948). Both Katayama and Ashida were sandwiched between governments led by conservative Yoshida Shigeru (who served as prime minister five times between 1946 and 1954).

${ }^{76}$ Dōmei nypzu mangahan dai nijpgo ban. (36cm x 26cm, PB0812: 1948.08. 01). Held in the Archives of the Ōhara Institute for Social Research, Hōsei Uni- versity.
} 


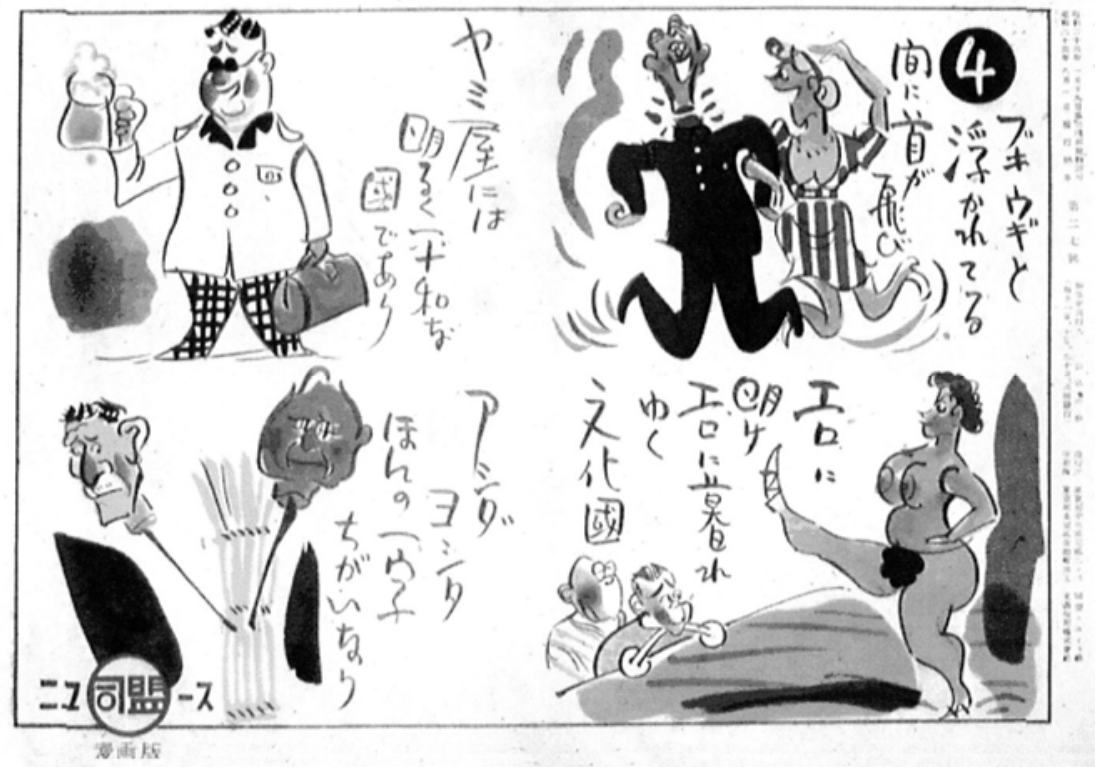

Figure 3. Bottom right: "Erotic Dawn; Erotic Dusk: [this is the] Cultural Nation (bunka kokka)." Bottom left: "Ashida; Yoshida - only the letters (kanji) are different." Katō Etsurō. Dōmei nypzu mangahan dai nijpgo ban. 36cm x 26cm. PB0812: 1 August 1948. (Digital image courtesy of the Ōhara Institute for Social Research, Tokyo.)

"erotic dawn; erotic dusk: [this is the] Cultural Nation." In the first scene Katō accuses the Yoshida and Ashida Governments of being unable to jump-start the sluggish post-war economy and thus they are complicit in the mass layoffs that had accompanied the economic downturn. In the second scene, however, Katō indicts former prime minister Yoshida for promoting policies that called for building Japan into a "Cultural Nation" (bunka kokka), which resulted in little more than a national fascination with the "erotic grotesquerie" (ero guro)..$^{77}$ In the third and fourth scene, Katō simultaneously condemns the Yoshida Government for the popular fascination with erotic culture and economic stagnation, decries the growing black market economy, and declares the Ashida government to be no different from that of its predecessor, Yoshida Shigeru. In effect, text and images together are the cornerstone of the artist's assertion hat the government, more concerned with promoting culture than fixing the economy, had failed at both. ${ }^{78}$

\footnotetext{
${ }^{77}$ In an unpublished conference paper, Peter Seigenthaler discusses Yoshida's call to rebuild Japanese society as a bunka kokka (a cultural nation) that coin- cides with the creation of the Yomiuri Bungaku Shō (Yomiuri Prize for Litera- ture) first established in 1948 by the Yomiuri Shimbun Company with the aim of building a "cultural nation." Siegenthaler 2000.

${ }^{78}$ Taylor Atkins (2001) has argued that jazz is as Japanese as it is American, and Katō's appropriation of a well-known song of the era does not itself signify a critique of "Americanization." However, the Andrews Sisters are one of the cultural icons that defined the U.S. wartime experience, and Katō may have been
} 


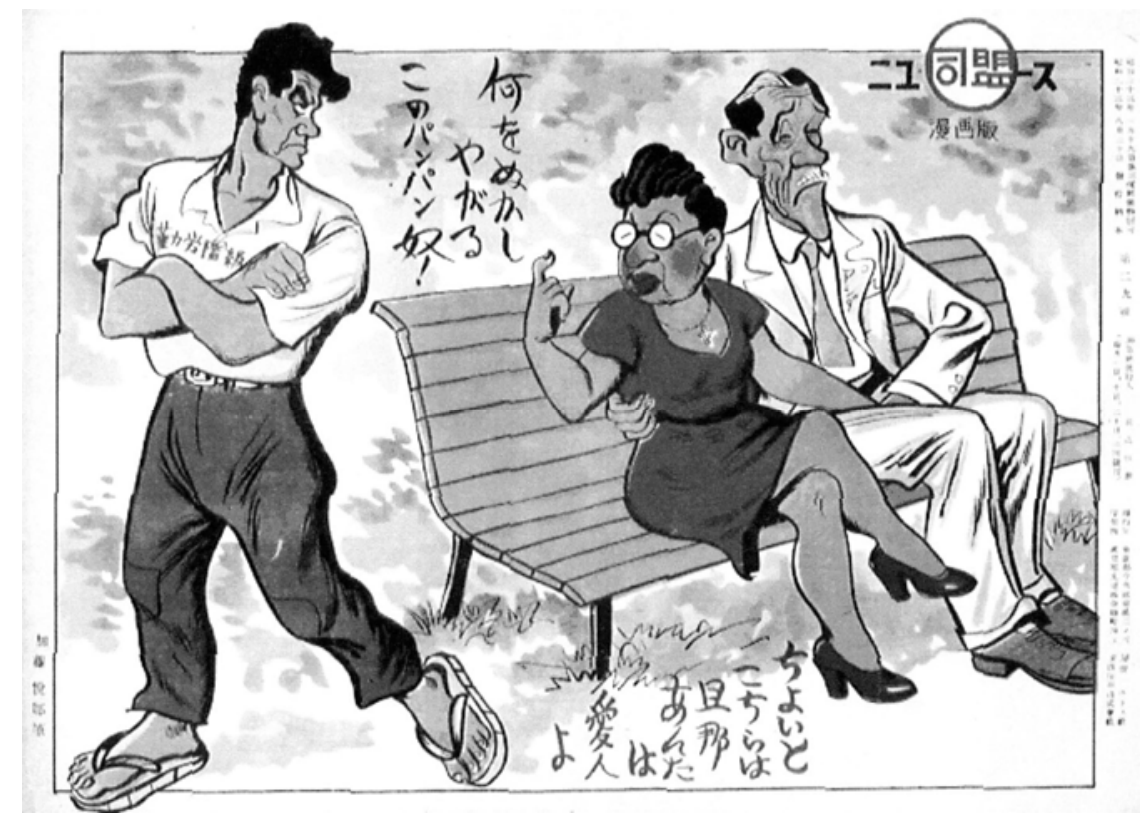

Figure 4. Text beneath the park bench: "This here [Ashida] is my danna (husband); you're my lover!" Text between prostitute and younger man: "Just who is this whore (pan-pan yakko) jacking off." Katō Etsurō. Dōmei nypzu mangahan dai nijpkyp ban. $36 \mathrm{~cm} \times 26 \mathrm{~cm}$. PB0814: 20 August 1948. (Digital image courtesy of the Ōhara Institute for Social Research, Tokyo.)

Within a few weeks of publishing his first "Boogie Woogie" panel, Katō expanded the scope of his attacks on the politically conservative Ashida Government to include its archrival, the Japan Socialist Party (JSP). Published in the 20 August edition of the Comic News, figure 4 portrays the JSP as a plump woman whose face resembles that of former socialist prime minister Katayama Tetsu. Katō illustrates Katayama wearing a red dress (identifying Katayama in the text across "her" lap as the Socialist Party), red high heels, and red lipstick. The cross-dressed Katayama (who here represents an odd twist on the eroticized female form) is seated on a park bench beside Prime Minister Ashida Hitoshi. ${ }^{79}$

Ashida appears to be holding Katayama's left hand as it is thrust into Ashida's crotch. With the forefinger of his/her other hand, Katayama beckons a stronglooking man standing off to the left of the frame (identified in the text as the

attempting to use the "Boogie Woogie Bugle Boy" to indict the whole of Japan as becoming too Americanized.

${ }^{79}$ Katō has also drawn Katayama, who was a Christian, wearing the kind of cruci- fix commonly worn by graduates of Christian girls high schools, which may be a subtle indictment of the Western influence of Katayama's religion. 
"working class") to come closer. ${ }^{80}$ In the red text at the bottom of the panel, the cross-dressed Katayama declares to the younger/more virile-looking working-class man that "this here [Ashida] is my danna [husband]; you're my lover!" In the strictest sense the term danna is the formal title for a woman's "husband." In the culture of sex work danna refers to a prostitute's preferred "client" or "patron." Katō is accusing the reigning conservative prime minister of being in a commercial sexual relationship with a former socialist one. ${ }^{81}$

If the implied sexual relationship between Katayama and Ashida were not already indictment enough, the artist Kato comments at the top of the panel, in a very coarse verb tense generally reserved for private discourse among working-class men, "Just who is this whore [pan-pan yakko] jacking off!" 82 While significant that Kato has for the first time deployed the pan-pan that he had to that point avoided, it is more significant still that he modifies the term pan-pan with the character yakko, which is a masculine suffix indicating the "servile" or "slavish" status of the object noun that simultaneously emphasizes the masculine voice of the intended reader. The gendered implications of the way Katō deploys the suffix emphasizes the "masculinity" of the reader and the "femininity" of the cross-dressed "whore," while the classed implications use masculine language to accentuate the slavish character of a leader of the Socialist Party found in the act of sexually servicing a conservative head of state.

At the core of the critique in figure 4 is a base sexual transaction between a cross-dressed prostitute and his/her client. However, Katō has also intertwined gendered, classed, and ethnicized language forms within a visual depiction of sexual commerce as the means of casting doubt on the political legitimacy of both the Socialist Party and the reigning Ashida Government. Vulgar and sarcastic, Katō was using sex talk to refashion working-class men's understanding of the political moment within which they were engaged. ${ }^{83}$

Perhaps more importantly, by labeling Katayama a pan-pan yakko, Katō had deployed an icon closely associated with the communist critique of U.S. hegemony, and may have been trying to style Katayama as a lackey of the Allied Occupation. While it is unclear whether Katō at this point intended to

\footnotetext{
${ }^{80}$ Significantly, Katō has partially asserted his political independence from the Socialist and Communist parties by identifying the masculine "worker" as the "working and salaried classes" (kinrō kaikyp), not rōdōsha kaikyb, which was a term in general use by the Japan Communist and Socialist parties.

${ }^{81}$ On cartoons and sexuality in Japan, see Allison 2000 and Napier 2001. On malemale sexuality and homosexual desire, see Pflugfelder 2000. On cross- dressing and gender identity, see Robertson 1998.

${ }^{82}$ Katō's use of the verb tense yagaru indicates that he most likely intended nukashi (nukasu) to mean "jack off," but could also have meant "putting out," "spewing," or "to omit saying."

${ }^{83} \mathrm{I}$ am speculating that two politicians exchanging in sexual services-for-hire might be read as an implied sexual contract between political agents whose bi- ological sex grants them access to the polis even while their public homosex- ual act undermines their claim to political legitimacy. See Pateman 1988.
} 
abandon a carefully fashioned strategy of avoiding ethnically charged criticism of the Allied Occupation forces, figure 5 clearly indicates that Kato had finally risked a subtle entrance into the kind of anti-imperialist discourse he had thus far avoided.

In the panel reproduced in figure 5 , from the same issue of the Comic News,

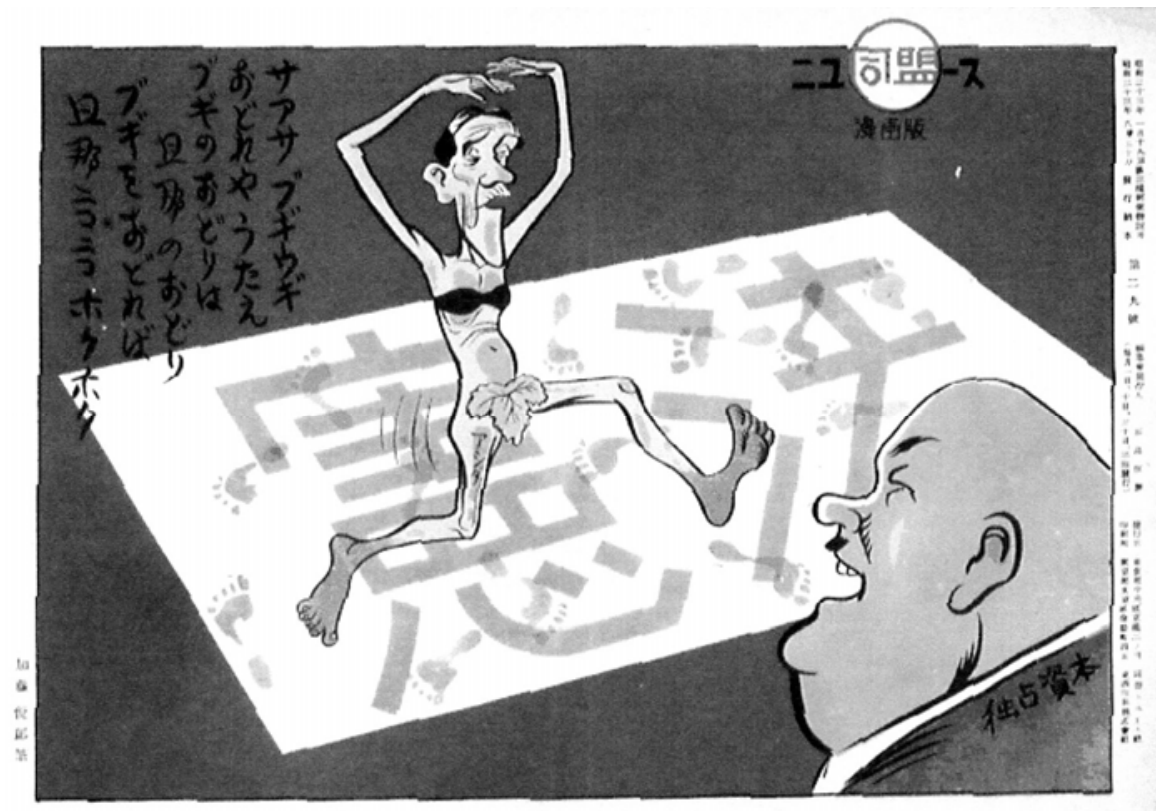

Figure 5. "Come on and dance and sing the boogie woogie / The boogie is [your] husband's/patron's dance / and your husband/patron won't frown when you dance the boogie." Katō Etsurō. Dōmei nypzu mangahan dai nijpkyp ban. $36 \mathrm{~cm}$ x $26 \mathrm{~cm}$. PB0816: 20 August 1948. (Digital image courtesy of the Ōhara Institute for Social Research, Tokyo.)

Katō portrays a cross-dressed Ashida as an erotic dancer. In this panel, a muddy-footed Ashida, wearing merely a brassiere and a fig leaf to cover his genitalia, dances on a large floor mat labeled "Constitution of Japan," while a man identified as "monopoly capital" stands gazing at the spectacle before him. The lyrics to the left of the frame exhort the dancing Ashida to please his "patron" (danna) by singing and dancing to the tune of the Andrews Sisters' "Boogie Woogie Bugle Boy."

Again, Katō invokes an eroticized feminine form in order to undermine the legitimacy of the political actors portrayed. However, Katō has also evoked his earlier use of "Boogie Woogie Bugle Boy" as the tune to which Ashida dances. Published within a few days of the annual festival of the ancestors (O-bon), the period of the summer when it is customary for women, young and old, to dance in memory of their patrilineal ancestors, Katō portrays a feminine Ashida as an erotic dancer trampling the Constitution to an American tune.$^{84}$ While the

\footnotetext{
${ }^{84}$ While the dance bears little resemblance to that performed to mark the O-bon, the timing of publication and the dissimilarity of the dance, accidentally or otherwise, may have informed the reader's interpretation of the erotic dance portrayed.
} 
text identifies the "Monopoly Capitalist" as the "patron" for whom Ashida performs what appears to be an erotic O-bon (danced by an emasculated Ashida), Katō subtly indicts the U.S.-dominated Allied Occupation, which had a month earlier (24 July) ordered the Ashida Government to strip public sector workers of their constitutional right to strike and ordered the suppression of the Tōhō Strike less than a week prior to publication of this issue of the Comic News. Indeed, Katō wanted the reader to understand that the source of Japan's political woe was the U.S. tune to which all political actors of the post-war stage danced.

Articulated and unarticulated notions of class, gender, and ethnicity converged in the late 1940s to form the backbone of labor's critique of American cultural and political dominance in Japan. Artists, working for politically moderate and leftist unions alike, deployed strongly gendered images as principal signifiers of the political debasement and betrayal of democracy they felt characterized the abrupt change in U.S. policies that accompanied the "Reverse Course" and subsequent onset of cold war era U.S.-Japan relations.

Both the NCIU and GFTU invested in a typology of the "feminine" that deployed classed and ethnicized vulgar-talk to convey political meaning in their cartoons and posters. While union artists deployed a complex array of cultural symbols at odds with their formal support of the equal status of women, the pan-pan stands out as the most damaging by far. Katō's cartoons used vulgar sex-talk in a way that only further debased the already castigated real-life pan-pan who worked unrepresented by organized labor. Neither the Tōhō poster nor Katō's cartoons allowed the pan-pan their own voice, nor reconciled the artists' or viewers' complicity in the colonial legacy of the pan-pan's social function and station. Ultimately, the pan-pan portrayed in the graphic art deployed by organized labor in 1948 gave political voice to marginalized men by concealing the colonial history of the men who deployed it.

The artists and union leaders who collaborated in making this propaganda do not appear to have been concerned about the repercussions that hostile sexand vulgar-talk might have for women, and it seems likely that the relegation of women to discursive roles antagonistic to their status as equals undermined their status within the unions to which they belonged. Indeed, union discourses that deployed the pan-pan reflect more about men's attitudes about sex and gender than they represented the actual women who comprised a third of union members. Just as significant, however, is that these artists and union leaders were culpable in propagating a discursive boundary marker that masked the continuities between the sexual regimes of wartime and post-war Japan. The consequences were substantive. Although union leaders courted women with platitudes about gender equity well into the 1950s, union women encountered tough resistance to their insistence on equal status to men. Union leaders seemed to prefer women in subordinate roles.

ACKNOWLEDGMENTS: I am indebted to the many friends and colleagues who have critiqued this essay along the way. In particular, I wish to thank Stephen Vlastos, Laura E. Hein, Linda K. Kerber, Wesley Sasaki-Uemura, Michael H. Gibbs, 
Shinoda Toru, David Tobaru Obermiller, Peter Siegenthaler, Fujiwara Tetsuya, Hans Martin Kramer, Philip Whalen, Will E. Hipps, Jennifer E. Anderson, and CAS peer reviewers Vera Mackie, Susan Napier, and Jennifer Robertson. I am also grateful for the extraordinary support I have received from the faculty and staff of the Ōhara Institute for Social Research at Hōsei University, the Council on East Asian Studies at Yale University, the Northeast Asia Council of the Association for Asian Studies, and the Japan Society for the Promotion of Science.

\section{References}

Allison, Anne. 2000. Permitted and prohibited desire: Mothers, comics, and censorship in Japan. Los Angeles and Berkeley: University of California Press.

Anderson, Joseph L., and Donald Richie. 1982. The Japanese film: Art and industry. Princeton, N.J.: Princeton University Press.

Atkins, Taylor. 2001. Blue Nippon: Authenticating jazz in Japan. Durham, N.C.: Duke University Press.

Bennett, John W. 2002. Women of the night. In Doing photography and social research in occupied Japan, 1948-1951. Ohio State University Library. www.lib.ohio-state.edu/rarweb/japan/. Accessed 26 October 2006.

Bernstein, Gail Lee. 1991. Recreating Japanese women, 1600-1945. Los Angeles and Berkeley: University of California Press.

Brewis, Joanna and Stephen Linstead. 2000. Sex, work, and sex work: Eroticizing organization. New York: Routledge.

Bucher, Greta. 2000. Struggling to survive: Soviet women in the post-war years. Journal of Women's History 12(1): 137-50.

Burkman, Thomas, ed. 1988. Occupation of Japan: arts and culture: The proceedings of the sixth symposium sponsored by the MacArthur Memorial, Old Dominion University, the General Douglas MacArthur Foundation, 18-19 October 1984. Norfolk: The Foundation.

Chapkis, Wendy, and Annie Sprinkle, eds. 1997. Live sex acts: Women performing erotic labor. New York: Routledge.

Delacosta, Frederique, ed. 1998. Sex work: Writings by women in the sex industry. New York: Cleis Press.

Diamond, Irene and Lee Quinby. 1998. Feminism and Foucault: Reflections on resistance. Boston: North-eastern University Press.

Doak, Kevin. 1997. What is a nation and who belongs? National narratives and the ethnic imagination in twentieth-century Japan. American Historical Review. 102 (2): 283-309.

Dower, John W. 1999. Embracing defeat: Japan in the wake of World War II. New York: W.W. Norton and Company/The New Press.

Faison, Elyssa. 2001. Producing Female Textile Workers in Imperial Japan. PhD diss. (University of California, Los Angeles, Dept. of History). 
Faue, Elizabeth. 1991. Community of suffering and struggle: Women, men, and the labor movement in Minneapolis, 1915-1945. Chapel Hill: University of North Carolina Press.

Fujime, Yuki. 2006. Japanese feminism and commercialized sex: The union of militarism and prohibitionism. Social Science Japan Journal 9 (1): 33-50.

Gayle, Curtis Anderson. 2002. Marxist history and post-war Japanese nationalism. London: RoutledgeCurzon.

Gerteis, Christopher. 2001. Japanese women, their unions, and the Security Treaty Struggle, 1945-1960. PhD diss. (University of lowa, Dept. of History). Gramsci, Antonio. 1967. Trans. L. Marks. The modern prince, and other writings. New York: International Publishers.

--- 1992. Trans. J.A. Buttigieg and A. Callari. Prison notebooks. New York: Columbia University Press.

Heineman, Lisa. 1999. What difference does a husband make: Women and marital status in Nazi and post-war Germany. Los Angeles and Berkeley: University of California Press.

Hicks, George. 1997. The Comfort women: Japan's brutal regime of enforced prostitution in the Second World War. New York: W.W. Norton.

Hirano, Kyoko. 1994. Mr. Smith goes to Tokyo: Japanese cinema under American occupation, 1945-52. New York: Smithsonian Books.

Ishikawa Masako. 1977. Konakatta ha gunkan dake I and II. Tokyo: Privately published and held in archives of the Ōhara Institute for Social Research, Tokyo.

Johnson, Merri Lisa. 2002. Jane sexes it up: True confessions of feminist desire. New York: Four Walls Eight Windows.

Katō Etsurō. 1960. Kato etsuro mangashu. Musashino: Katō etsurō mangashu kankokai.

Katogawa Naoki. 1947. Waga seishun nikui nashi. Eigahyōron. 4 (1): 29-33. Kim, Elaine H., and Chungmoo Choi, eds. 1998. Dangerous women: Gender and Korean nationalism. New York: Routledge.

Koschmann, Victor. 2005. REVIEW: Marxist history and post-war Japanese nationalism, Journal of Japanese Studies. 31 (2).

Kurosawa, Akira. 1982. Trans. A. Bock. Something like an autobiography. New York: Alfred A. Knopf.

Lenin, V.I. 1970. Collected works. Moscow: Foreign Language Publishing House.

Liang, Ellen Johnston. 1988. The winking owl: Art in the People's Republic of China. Los Angeles and Berkeley: University of California Press.

Mackie, Vera. 1997. Creating socialist women in Japan: Gender, labour, and activism, 1900-1937. Cambridge: Cambridge University Press.

Mackie, Vera. 2000. Modern selves and modern spaces. In Tipton and Clark 2000. 
- - . 2003. Feminism in modern Japan. Cambridge: Cambridge University Press.

Miyake, Yoshiko. 1991. Doubling expectations: Motherhood and women's factory work under state management in the 1930s and 1940s. In Bernstein 1991.

Miyamori Shigeru. 2002. Tōhō Sōgi tsuisō - Konakatta gunakan dake. Tokyo: Miharu Shuppansha.

Molasky, Michael S. 1999. The American occupation of Japan and Okinawa: Literature and memory. New York: Routledge.

Molony, Barbara. 1991. Activism among women in the taishō cotton textile industry. In Bernstein 1991.

Moore, Joe B. 1983. Japanese workers and the struggle for power, 1945-1947. Madison: University of Wisconsin Press.

- - . 1991. Purging tōhō cinema. Canadian Journal of History 26 (3): 453-78.

Morris-Suzuki, Tessa. 1998. Re-inventing Japan: Time, space, nation. Armonk, N.Y.: M.E. Sharpe.

Napier, Susan. 2001. Anime from Akira to Princess Mononoke: Experiencing contemporary Japanese animation. New York: Palgrave/Macmillan.

Ōkōchi Kazuo. 1969. Nihon rōdō kumiai Monogatari: Sengo I and II. Tokyo: Chikuma Shobō.

Ōkōchi Kazuo, ed. 1966. Shiryō sengo nijpnen shi. 4 vols. Tokyo: Nihon hyoren sha.

Okōchi Toshio. 1948. Tōhō sōgi no arashi ni tatsu: kubikiri mitsu. Senpu. 1 July. Osokina, Elena. 2001. Our daily bread: Socialist distribution and the art of survival in Stalin's Russia, 1927-1941. Armonk, N.Y.: M.E. Sharpe. Pateman, Carol. 1988. The sexual contract. Cambridge: Polity Press. Pflugfelder, Gregory. 2000. Cartographies of desire: Male-male sexuality in Japanese discourse, 1600-1950. Los Angeles and Berkeley: University of California Press.

Price, John. 1997. Japan works: Power and paradox in post-war industrial relations. Ithaca, N.Y.: Cornell University Press.

Richie, Donald. 1988. Setsuko Hara.

www.ozuyasujiro.com/resources/setsukohara.htm. Accessed 26 October 2006.

Ricketts, Robert. 1995. Zainichi chōsen no minzoku jishuken no hakai-katei: 1948-1949 wo chpshin ni. In Seikyp gakujutsu ronshp. Kankoku Bunka Kenkyp Shinkō Zaidan.

Robertson, Jennifer E. 1998. Takarazuka: Sexual politics and popular culture in modern Japan. Los Angeles and Berkeley: University of California Press.

Roundtable 1971. Konakatta ha gunkan dake - Tōhō sōgi zadankai. Gendai to shiso. September: 164-91.

Sanders, Holly Vincele. 2005. Prostitution in post-war Japan: Debt and labor. PhD diss. (Princeton University, Dept. of History). 
Schonberger, Howard. 1989. Aftermath of war: Americans and the remaking of Japan, 1945-1952. Kent, Ohio: Kent State University Press.

Siegenthaler, Peter. 2000. Yoshida's bunka kokka: Building a cultural nation in the post-war era. Paper presented to the annual meeting of the Southwest Conference on Asian Studies, University of Houston, Houston, Texas. 14 October.

Sievers, Sharon. 1987. Flowers in salt: The beginnings of feminist consciousness in modern Japan. Palo Alto, Calif.: Stanford University Press.

Smith, Steven D., Keith Krawczynski, and Robert F. Jefferson, eds. 2002. Victory and context: Recognition of African American contributions to American military history. www.denix.osd.mil/denix/Public/ESPrograms/Conservation/Legacy/AAME/aame.html. Accessed 26 October 2006. Sodei, Rinjiro, and John Dower. 1988. Satire under the occupation: The case of political cartoons. In Burkman 1988.

Stalin, J.V. 1955. Collected works. Moscow: Foreign Languages Publishing House.

Takahashi Hisako, et al. 1992. Sengo fujin rōdō seikatsu chōsa shiryōshû. Seikatsu hen - dai hachi hen - rōdō kumiai. Tokyo: Kuresu shuppan.

Takemae Eiji. 2002. The allied occupation of Japan. New York: Continuum. Takeuchi, Michiko. 2001. Gendered states: "Pan-pan girls" in the U.S. Occupation in Japan. MA thesis. (California State University, Long Beach, Dept. of History).

Tamanoi, Mariko. 1998. Under the shadow of nationalism: Politics and poetics of rural Japanese women. Honolulu: University of Hawaii Press.

- - . 1999. Japanese nationalism and the female body: A critical reassessment of the discourse of social reformers on factory women. In Walthall and Tonomura 1999.

Tanaka, Yuki. 2002. Japan's comfort women: The military and involuntary prostitution during war and occupation. New York: Routledge.

Tipton, Elise, and John Clark. 2000. Being modern in Japan. Sydney: Gordon and Breach Arts International.

Tōgō Atsushi. 1946. Kagayaku zenshin: Hara Setsuko no konogoro. Eigafaan 1 (3): 26-27.

Tsurumi, Patricia. 1991. Factory girls: Women in the thread mills of Meiji Japan. Princeton, N.J.: Princeton University Press.

Walthall, Anne, and Hitomi Tonomura. 1999. Women and class in Japanese history. Ann Arbor: University of Michigan Press.

Watanabe Tetsuzō. 1956. Hansen hankyo 40-nen. Tokyo: Jiyu ajia sha. Yamamoto Kiyoshi. 1986. Tōhō Sōgi (1948-nen) Shiryō. 2 vols. Tokyo: Tokyo Daigaku Shakai Kagaku Kenkyujo. 